The University of Maine

\title{
DigitalCommons@UMaine
}

Earth Science Faculty Scholarship

Earth Sciences

1979

\section{Experimental Metamorphic Petrology}

Joseph V. Chernosky Jr.

University of Maine - Main, josephc@maine.edu

Follow this and additional works at: https://digitalcommons.library.umaine.edu/ers_facpub

Part of the Earth Sciences Commons

\section{Repository Citation}

Chernosky, Joseph V. Jr., "Experimental Metamorphic Petrology" (1979). Earth Science Faculty Scholarship. 166.

https://digitalcommons.library.umaine.edu/ers_facpub/166

This Review is brought to you for free and open access by DigitalCommons@UMaine. It has been accepted for inclusion in Earth Science Faculty Scholarship by an authorized administrator of DigitalCommons@UMaine. For more information, please contact 
aqueous solutions, Brit. Geomorph. Res. Group Tech. Bull. 20, 48 p., 1977.

Wigley, T. M. L., and L. N. Plummer, Mixing of carbonate groundwaters, Geochim. Cosmochim. Acta, 40, 989-995, 1976.

Wolery, T. J., Some chemical aspects of hydrothermal processes at mid-oceanic ridges a theoretical study. I. Basalt - sea water reaction and chemical cycling between the oceanic crust and the oceans. II. Calculation of chemical equilibrium between aqueous solutions and minerals, Ph.D. thesis, Northwestern Univ., Evanston, Illinois, 1978.
Wong, G. T. F., and P. G. Brewer, The determination of iodine in seawater by instrumental neutron activation analysis, Anal. Chim. Acta., 81, 81-90, 1976.

Wong, G. T. F., and P. G. Brewer, The marine chemistry of lodine in anoxic basins, Geochim. Cosmochim. Acta, 41, 151-159, 1977.

Wood, B. J., Mixing properties of Tschermakitic clinopyroxenes, Am. Mineral., 61, 599-602, 1976.

Wood, J. R., Thermodynamics of brine-salt equilibria-I. The systems $\mathrm{NaCl}-\mathrm{KCl}-\mathrm{MgCl}_{2}-\mathrm{CaCl}_{2}-\mathrm{H}_{2} \mathrm{O}$ and $\mathrm{NaCl}-\mathrm{MgSO}_{4}$ at $25^{\circ} \mathrm{C}$, Geochim. Cosmochim. Acta, 39, $1147-1163,1975$.

VOL. 17, NO. 4

REVIEWS OF GEOPHYSICS AND SPACE PHYSICS

JUNE 1979

\section{EXPERIMENTAL METAMORPHIC PETROLOGY}

Joseph V. Chernosky, Jr.

Department of Geological Sciences, University of Maine at Orono, Orono, Maine 04473

\section{Introduction}

Since Bowen and Tuttle's pioneering study of the system $\mathrm{MgO}-\mathrm{SiO}_{2}-\mathrm{H}_{2} \mathrm{O}$ In 1949, advances in experimental metamorphic petrology have occurred steadily rather than in "leaps and bounds". The number and quality of papers published during the past quadrennium, 1975-1978, attests to the health of the science. Although the purpose of this report is to focus international attention on the U.S. effort in experimental metamorphic petrology, some papers published by foreign experimentalists have been included, especially where their contributions complement those made In the U.S. To keep the review current, abstracts of papers read at national meetings of the Geological Society of America and the American Geophysical Union In 1978 are included.

Coverage is generally limited to papers reporting experimental data acquired at pressures below $10 \mathrm{kbar}$ and temperatures between $200^{\circ} \mathrm{C}$ and the solidus for the system in question. Several papers reporting calorimetric and experimental data for pressures and temperature outside these limits were included to demonstrate how experimental metamorphic petrology interfaces with calorimetry, low temperature geochemistry, and experimental igneous petrology.

Papers are grouped into nine categories and are cross-referenced where necessary. Papers reporting experimental data for silicates have been subdivided according to the structural group of the dominant phase or phases whereas papers dealing with non-silicates are grouped together regardless of structure or composition. Papers dealing with multicomponent chemical systems are grouped under the heading "Rock Systems". Papers dealing with experimental techniques or with the calculation of thermochemical parameters of minerals are grouped under the headings "Experimental Techniques" and "General Physical Chemistry", respectively.

This paper is not subfect to U.S. copyright. Published in 1979 by the American Geophysical Union.
Discussion

With the realization that many important equilibria could not be investigated in the laboratory, experimentalists turned to thermodynamic theory in order to extrapolate experimentally determined equilibria to conditions not amenable to experiment, to calculate the effects of additional components, and to evaluate the consequences of varying intensive parameters. Unfortunately, many of the early experimental data are not sufficiently accurate for such calculations. In order to be useful for thermochemical calculations, phase equilibrium data must be reversed, activities of components In the fluid phase must be determined, and solid phases must be thoroughly characterlzed chemtcally, mineralogically, and structurally (orderdisorder, vacancies, polytypism, etc.)。

Several techniques developed or refined during the past quadrennium will aid the experimentalist in controlling fluid composition in hydrothermal experiments. The "Shaw apparatus" was redesigned [Frantz et al., 1977] because $\mathrm{H}_{2}$-equilibration times in the original design resulted in $\mathrm{f}_{\mathrm{O}_{2}}$ values lower than the equilibrium values [Hewitt, 1977]。Chou [1978] recalibrated the (FMQ), (MH), ( $\left.\mathrm{MnO}-\mathrm{Mn}_{3} \mathrm{O}_{4}\right),(\mathrm{NNO})$, and $(\mathrm{Co}-\mathrm{CoO})$ oxygen fugacity buffers; Hewitt [1978] recalibrated (FMQ)。Although Hewitt's recalibration differs from Chou's by no more than $0.5 \mathrm{log}$ units, the discrepancy must be resolved if the phase equilibrium data generated using (FMQ) are to be used for thermochemical calculations. The $\mathrm{Ag}+\mathrm{AgCl}$ acid buffer was recalibrated by Chou and Frantz [1977]; Frantz and Popp [1977] modified this buffer technique in order to determine speciation in hydrothermal fluids. Hallam and Eugster [1976] developed a method for buffering fluids in the system $\mathrm{N}-\mathrm{O}-\mathrm{H}$ by combining the $(\mathrm{Cr}+\mathrm{CrN})$ nitrogen buffer with conventional hydrogen buffers. Modifications of a chloride electrode and a flow-cell calorimeter by Popp et al. [1978] allow accurate and precise measurement of chloride ion in the concentration range 0.01 to $0.0001 \mathrm{~m}$ in microvolume samples $(1-10 \mu \ell)$. 
Ziegenbein and Johannes [1977] designed a device which alds in the extraction and gaschromatographic analysis of fluids present in high pressure experiments. Schmid et al。 [1978] developed a sensitive method for determining reaction direction in experiments where one of the reacting phases is a solid solution of two components. Navrotsky [1978] designed a microcalorimeter which can accept a cold-seal pressure vessel and is using the apparatus to measure enthalpies of aqueous solutions at pressures to $2 \mathrm{kbar}$ and temperatures to $800^{\circ} \mathrm{C}$.

During the past quadrennium, experimental studies were initiated to determine the compositional limits of micas [Hazen and Wones, 1978; Franz and Althaus, 1976], phlogopite [Robert, 1976a, b], brittle micas [01esch, 1975], kornerupine [Werding and Schreyer, 1978], viridine [Abs-Wurmbach and Langer, 1975], and sapphirine [Bishop and Newton, 1975]. Successful synthesis of clinoptilolite [Goto, 1977], spodumene [Drysdale, 1975], carpholite [Mottana and Schreyer, 1977], and a triple chain silicate [Tateyama et a1., 1978] was achieved.

Among the dehydration equilibria whose locations in $\mathrm{P}_{\mathrm{H}_{2}} \mathrm{O}^{-\mathrm{T}}$ space have been refined are reactions involving anthophyllite [Ravior and Hinricksen, 1975; Chernosky, 1976], phlogopite [Wones and Dodge, 1977], tremolite [McKinstry and Skippen, 1978], sillimanite + biotite + quartz [Hoffer, 1976], clinochlore [Staudigel and Schreyer, 1977], clinochlore + quartz [Chernosky, 1978], portlandite, and brucite [Irving et al., 1977]. Experimentalists have successfully reversed equilibria involving bicchulite [Gupta and Chatterjee, 1978], margarite [Chatterjee, 1976], lizardite [Chernosky, 1978], gehlenite [Huckenholz, 1977], and antigorite [Evans et al., 1976].

Considerable effort has been expended in determining the stabilities and phase relations of crystalline solutions. Such studies require that the compositions of the coexisting phases be determined. Determinative curves relating the unit cell parameters of a phase to its composition have been experimentally calibrated for piemontite [Anastasiou and Langer, 1977], Fe-Mg orthoamphiboles [Popp et al., 1976], orthoamphibole [Maresch and Langer, 1976], Fe-Mg-A1 biotites [Hewitt and Wones, 1975], Mg-Al serpentines [Chernosky, 1975], nepheline-kalsilite [Ferry and Blencoe, 1978], OH-F amblygonite [Loh and Wise, 1976], edenite-pargasite [Hinricksen and Schürmann, 1977], pargasite-richterite [Braue and Seck, 1977], and grandidierite [01esch and Seifert, 1976].

Among the crystalline solutions whose stabilities and phase relations have been determined are nepheline-kalsilite [Ferry and Blencoe, 1978], pyrope-grossular [Herisen, 1976], uvaroviteandradite and uvarovite-grossularite [Huckenholz and Knettel, 1976], grossularite-spessartine [Hsu, 1978], pargasite-richterite [Braue and Seck, 1977], richterite-ferrorichterite [Charles, 1975, 1977], actinolite-cummingtonite [Cameron, 1975], hastingsite [Charles, 1978], grunerite [Forbes, 1977], Fe-Mg amphiboles [Popp et al., 1977a], chlorite [McOnie et al., 1975; Fleming and Fawcett, 1976; James et al., 1976], serpentine [Moody, 1976], cordierite [Holdaway, 1976; Holdaway and Lee, 1977; Lee and Holdaway,
1976], calcium brittle micas [Olesch and Seifert, 1976], and pyroxenes [Warner, 1975; Lindsley and Dixon, 1976; Ikeda and Yagi, 1977; Herzberg, 1978; and Wood, 1978].

Experimental calibration of the temperature, pressure and compositional dependence of major and trace element distribution coefficients may enable them to be used as geothermometers and geobarometers. The partitioning of $\mathrm{Fe}$ and $\mathrm{Mg}$ between biotite-garnet [Ferry and Spear, 1978], garnet-phengite [Krogh and Råheim, 1978], olivine-spinel [Engi, 1978], and biotite-salt solution [Schulien, 1975] were determined experimentally. Rajamani [1976] investigated the distribution of $\mathrm{Fe}, \mathrm{Co}$, and $\mathrm{Ni}$ between sulfide and orthopyroxene. Jacobson and Usdowsk1 [1976] investigated the partitioning of $\mathrm{Sr}$ between calcite and dolomite, Suvorva and Tenishev [1976] determined the distribution of sulfur isotopes between $\mathrm{Mo}, \mathrm{Pb}, \mathrm{Zn}$ and $\mathrm{Sn}$ sulfides, and Fournier [1976] studied the exchange of $\mathrm{Na}^{+}$and $\mathrm{K}^{+}$between water vapor and feldspar. Fluorinehydroxyl exchange was experimentally investigated for topaz [Rosenberg, 1978], muscovite [Munoz and Ludington, 1977], and amblygonite [Loh and Wise, 1976].

Experimental data for reactions involving a $\mathrm{C}-\mathrm{O}-\mathrm{H}$ fluid phase have been obtained for sphene [Hunt and Kerrick, 1977], andradite [Taylor and Liou, 1978], grossular, and wollastonite

[Shonulovich, 1977], rhodochrosite [Candia et al。, 1975], siderite [Chou, 1978], and zeolites [Ivanov and Gurevich, 1975]. Novgorodov [1975, 1977] investigated the solubility of quartz in $\mathrm{H}_{2} \mathrm{O}-\mathrm{CO}_{2}$ mixtures. Locations of key equilibria in multicomponent systems involving $\mathrm{C}-\mathrm{O}-\mathrm{H}$ fluids were experimentally determined by Slaughter et al. [1975], Hewitt [1975], Metz [1976], Zharikov et al. [1977], and Puhan [1978]. Devolatilization equilibria in graphitic systems were discussed by Ohmoto and Kerrick [1977].

The stability relations of scapolite received considerable attention from experimentalists; Orville [1975] and Goldsmith and Newton [1977] investigated scapolite-plagioclase phase relations, Ellis [1978] investigated chloride and carbonate bearing scapolites, Newton and Goldsmith [1975] investigated the stability of meionite, and Goldsmith [1976] discussed the role of scapolite as a reservoir of $\mathrm{CO}_{2}$ and sulfur in the lower crust.

Natural metamorphic fluids contain acids, salts, ions, and complexes as well as gases. The composition of a fluid in equilibrium with a particular metamorphic mineral assemblage can in principle be determined provided the assemblage contains fugacity indicators and appropriate buffer and exchange reactions [Eugster, 1977]. The success of this approach is limited because thermodynamic data for aqueous species at high temperatures and pressures is often unavailable. Although laboratory calibrations of equilibria involving multicomponent gases and aqueous electrolytes are uncommon, solubility studies continue to provide valuable information on the stabilities and thermochemical parameters of minerals and solutions. Solubilities of fron [Popp and Frantz, 1977], fluorspar [Malinin, 1976], wollastonite [Gunter and Eugster, 1978], mullite [Ostapenko et al., 1975], talc, antigorite, forsterite, chrysotile, brucite, and 
enstatite [Hemley et al., 1977a, b] were measured. Frantz and Popp [1978] investigated speciation of aqueous $\mathrm{MgCl}_{2}$ in the system $\mathrm{MgO}-\mathrm{SiO}_{2}-\mathrm{H}_{2} \mathrm{O}-\mathrm{HCl}$ and found that at a total pressure of $2 \mathrm{kbar}$, associated $\mathrm{MgCl}_{2}$ is the dominant magnesium species in the fluid at temperatures above $550^{\circ} \mathrm{C}$ whereas $\mathrm{Mg}^{2+}$ lons were dominant at temperatures below $400^{\circ} \mathrm{C}$. Experimental data for solution-rock equilibria have been obtained for seawaterbasalt [Mott1 and Holland, 1978], seawaterperidotite [Seyfried and Dibble, 1978], seawaterandesite [Liou and Dickson, 1978], NaCl solutioncarbonate rock [Radtke et al., 1978], and aqueous chloride solution-two mica schist [Vidale, 1975].

Textural relations in metamorphic rocks and ore deposits suggest that sulfides, silicates, and oxides often coexist stably. Experimental studies on sulfide-silicate phase relations remain uncommon despite the economic importance of sulfide deposits. A notable exception is the study of amphibole-magnetite-pyrrhotite phase equilibria by Popp et al. [1977] which hopefully will pave the way for future experimental work on sulfide-silicate phase relations. We must understand how and to what extent metals and sulfur dissolve and are transported in order to understand the ore deposition process. Experimental studies on the replacement of marble by sulfides [Howd and Barnes, 1975], on the mobility of metals in aqueous solutions [Govett et al., 1976; Giblin, 1978], on the solubility of chalcocite [Crerar and Barnes, 1976], scheelite [Foster, 1977], iron [Popp and Frantz, 1977], barite [Blount, 1977], and pyrite + pyrrhotite + magnetite [Crerar et a1., 1978] provide the type of information required to understand ore genesis.

The processes of nucleation and growth (including diffusion and reaction rates) require further investigation before mechanisms by which metamorphic reactions proceed can be fully understood. Laboratory studies which enhance our understanding of diffusion and reaction rates include those of Hoffman et al. [1975], Wyart [1975], Kalinin and Shapovalova [1975], Seifert and Virgo [1975], Sipling and Yund [1976], McCallister and Yund [1977], Kay [1973], Sakai and Dickson [1978], Ildefonse and Gabis [1976], Lagache [1976], and Grandstaff [1976].

Methods for calculating reaction entropies and enthalpies from reversed phase equilibrium data were proposed by Gordon [1977] and Chatterjee [1975, 1977]; Anderson [1976, 1977] discussed uncertainties involved in such calculations and suggested that errors could be evaluated using a Monte Carlo method. Techniques for calculating and extrapolating equilibria in $\mathrm{P}-\mathrm{T}-\mathrm{X}_{\mathrm{CO}}$ space have been discussed by Skippen [1975], Skippen and Carmichael [1977] and Kerrick et al. [1976] and have been compared by Kerrick and Slaughter [1976] and Kerrick and Jacobs [1978].

Thermodynamic parameters for diaspore, margarite, pyrophyllite, zoisite, wairakite [Chatterjee, 1976], bicchulite [Gupta and Chatterjee, 1978], hydrous phlogopite [Wones and Dodge, 1977], talc, anthophyllite, enstatite, chrysotile [Zen and Chernosky, 1976], and andradite [Taylor and Liou, 1978] were extracted from phase equilibrium data. Thermodynamic properties of mullite [Ostapenko et al., 1975], barite [Blount, 1977], talc, antigorite, anthophyllite, chrysotile [Hemley et al., 1977a, b], and supercritical aqueous $\mathrm{CaCl}_{2}$ [Gunter and Eugster, 1978] were extracted from solubility data.

The relationship between activity and composition for rock-forming crystalline solutions is required to calculate equilibrium conditions in complex natural systems using thermodynamic principles. Activity-composition relations for pyrope-grossular [Hensen et al., 1975], almandinegrossular [Cressey et al.., 1978], muscoviteparagonite [Chatterjee and Froese, 1975], magnetite-ilmenite [Lindsley, 1978; Spencer and Lindsley, 1978], high albite-sanidine [Blencoe and Merkel, 1978] were extracted from phase equilibrium data using various solution models.

Procedures for estimating thermodynamic properties of minerals have been proposed by Chen [1975], Saxena [1976], Tardy and Garrels [1976, 1977], Tardy and Gartner [1977], Tardy and Vieillard [1977], Dibble and Dickson [1978], and Helgeson et al. [1978]. Ulbrich and Waldbaum [1976] emphasized the need for considering structural contributions to the third-law entropies of silicates. The thermodynamics of metamorphic fluids was discussed by Ryzhenko [1976], Eugster [1977], and Holloway [1977]; an equation of state for aqueous species at infinite dilution has been predicted by Helgeson and Kirkham [1976]. Fugacity coefficients for $\mathrm{CO}_{2}$ have been calculated by Shmulovich and Shmonov [1975].

Among the minerals investigated calorimetrically are garnets [Kiseleva, 1976b; Kiseleva and Topor, 1976; Perkins et al., 1977; Kolesnik et al., 1977; Kiseleva, 1977; Newton et al., 1977; Charlu et al., 1975, 1978], pyroxenes [Navrotsky and Coons, 1976; Newton et al., 1977; Thompson et a1., 1978; Char1u et a1., 1975], spinel [Navrotsky and Kasper, 1976], gedrite [Kolesnik et al., 1976], sapphirine [Kiseleva, 1976a], gibbsite [Hemingway and Robie, 1977; Hemingway et al., 1977], kaolinite [Hemingway et al., 1978], muscovite [Robie et al., 1976], low albite [Hemingway and Robie, 1977], anorthite [Robie et al., 1978] and alkali feldspar [Hovis and Waldbaum, 1977]. Comprehensive computer programs designed to evaluate and correlate calorimetric and phase equilibrium data were written by Haas and Fisher [1976] and Helgeson et al. [1978]. During the quadrennium, two internally-consistent compilations of thermodynamic properties of rock-forming minerals were published; one is based on calorimetric data [Robie et al., 1978] whereas the other is primarily based on phase equilibrium data [Helgeson et al., 1978]. Although the thermochemical properties for many minerals in these compilations are similar, there are significant differences which the experimentalist is challenged to resolve.

\section{The Future}

One of the chief goals of the modern metamorphic petrologist is to determine the physiochemical conditions prevailing at the time a given metamorphic rock was recrystallized. Toward this end, experimentalists have explored the role of intensive parameters such as total pressure, water pressure, temperature, and oxygen fugacity in detail. Until recently, 
however, the nature, composition, and role of the supercritical metamorphic fluid has not received much attention from experimentalists. Now that techniques for studying acid-base, dissociation, and solubility reactions at elevated temperatures and pressures have been developed, experimental work on the solution chemistry of metamorphic supercritical flulds will flourish.

The petrologic community is in need of experimental data for a wide range of topics: actlvity-composition relations for most rockforming crystalline solutions need to be determined; diffusion coefficients for aqueous species and lons at metamorphic conditions are virtually unknown; the distribution of major and trace elements among most important metamorphic mineral pairs remains to be calibrated experimentally. Unfortunately, the current funding picture and the paucity of academic positions for scientists trained in experimental petrology preclude radical changes in the level of activity. Consequently, equilibria which provide the most useful information must be identified in order to maximize efficient use of equipment and time.

In the past decade it has become evident that phase equilibrium data can be used as input for thermochemical calculations. Consequently, considerable effort will be directed toward investigating relatively simple equilibria involving key phases even though such reactions may not be observed to occur in rocks. Although the traditional approach which involves mapping out the stability field for a particular mineral or assemblage will be retained, experimental techniques must and will be sharpened to the point that brackets $5-10^{\circ} \mathrm{C}$ wide will be routinely obtained. Narrow brackets are necessary if the thermochemical parameters of minerals are to be refined. Precise and accurate techniques for determining the composition of fine-grained material must be developed. The discovery of triple chain silicates in natural and synthetic phases [Veblen et al, 1978], for example, emphasizes the need to evaluate starting materials more critically. Interlaboratory calibration of hydrochemical equipment is necessary to insure internal consistency among data obtained in different laboratories.

The ability to measure high temperature heat capacities of relatively small synthetic samples with a differential scanning calorimeter is a major development. High temperature heat capacity data for many rock-forming minerals and crystalline solutions will become available during the next quadrennium. The possibility of routinely measuring the high temperature heat capacities of phases used in starting materials for hydrothermal experiments now exists!

The development of computer programs for correlating and extrapolating phase equilibrium and calorimetric data challenges the experimentalist to insure that new experimental data are consistent with the corpus of existing phase equilibrium and thermodynamic data.

\section{Experimental Techniques}

Adams, H. G., L. H. Cohen, and J. L. Rosenfeld, Solid inclusion piezothermometry I: Comparison dilatometry, Amer. Mineral., 60, 574-583, 1975.
Adams, H. G., L. H. Cohen, and J. L. Rosenfeld, Solid inclusion piezothermometry II: Geometric basis, calibration for the association quartzgarnet, and applications to some pelitic schists, Amer. Mineral., 60, 584-598, 1975.

Chou, I.-M., Calibration of oxygen buffers at elevated $P$ and $T$ using the hydrogen fugacity sensor, Amer. Mineral., 63, 690-703, 1978.

Chou, I.-M., and H. P. Eugster, Fugacity control and dissoclation constants of $\mathrm{HBr}$ and $\mathrm{HI}$, Contr. Nineral. Petrol., 56, 77-100, 1976.

Chou, I.-M., and J. D. Frantz, Recalibration of $\mathrm{Ag}+\mathrm{AgCl}$ acid buffer at elevated pressures and temperatures, Amer. J. Sc1., 277, 1067$1072,1977$.

Chou, I.-M. , H. P. Eugster, P. Berens, and J. H. Weare, Diffusion of hydrogen through platinum membranes at high pressures and temperatures, Geochim. Cosmochim. Acta, 42, 281-288, 1978.

Finnerty, T. A., G. A. Waychunas, and W. M. Thomas, The preparation of starting mixes for mineral syntheses by a freeze-dry technique, Amer. Mineral., 63, 415-418, 1978.

Frantz, J. D., and R. Popp, Modification of the $\mathrm{Ag}+\mathrm{AgCl}$ buffering technique for the determination of speciation in hydrothermal fluids, Carnegie Inst. Wash. Yearb., 76, 598-601, 1977.

Frantz, J. D., J. M. Ferry, R. K. Popp, and D. A. Hewitt, Redesign of the "Shaw Apparatus" for controlled hydrogen fugacity during hydrothermal experimentation, Carnegie Inst. Wash. Yearb., 76, 660-662, 1977.

Ha11am, M., and H. P. Eugster, Ammonlum sllicate stability relations, Contr. Mineral. Petro1., 57, 227-244, 1976.

Hewitt, D. A., Hydrogen fugacities in Shaw bomb experiments, Contr. Mineral. Petro1., 65, $165-169,1977$.

Hewitt, D. A., A redetermination of the fayalitemagnetite-quartz equilibrium between $650^{\circ}$ and $850^{\circ} \mathrm{C}$, Amer. J. Sci., 278, 715-724, 1978.

Huebner, J. S., Oxygen fugacity values of furnace gas mixtures, Amer. Mineral., 60, 815-823, 1975 .

Johannes, W., Pressure comparing experiments with $\mathrm{NaCl}, \mathrm{AgCl}$, talc, and pyrophyllite assemblies In a piston cylinder apparatus, Neues. Jahrb. Mineral. Mont., 2, 84-92, 1978.

Ludington, S., Temperature gradients in rapidquench cold-seal pressure vessels--the effect of inclination, Geol. Soc. Amer. Abstracts with Programs, 10, 447, 1978.

Makovicky, M., and J. Rose-Hansen, Teflon capsule for hydrothermal runs in high-pressure bombs, Neues. Jahrb. Mineral. Mont., 12, 559-560, 1977.

Navrotsky, A., Progress and new directions in high temperature calorimetry, Phys. Chem. Minerals, 2, 89-104, 1977.

Popp, R. K., and J. D. Frantz, Diffusion of hydrogen in gold, Carnegie Inst. Wash. Yearb., $76,662-664,1977$.

Popp, R. K., J. D. Frantz, G. L. Vogel, and P. E. Hare, Measurement of chloride ion concentrations in microsamples, Carnegie Inst. Wash. Yearb., 77, 912-917, 1978.

Potter, R. W., II, R. S. Babcock, and D. L. Brown, A new method for determining the solubility of salts in aqueous solutions at elevated temperatures, J. Res. U. S. Geo1. Survey, 5, 389-395, 1977 . 
Roeder, P. L., and J. M. Dixon, A centrifuge furnace for separating phases at high temperature in experimental petrology, Can. J. Earth Sci., 14, 1077-1084, 1977.

Rudert, V., I.-M. Chou, and H. P. Eugster, Temperature gradients in rapid-quench coldseal pressure vessels, Amer. Mineral., 61, 1012-1015, 1976.

Schmid, R., G. Cressey, and B. J. Wood, Experimental determination of univariant equilibria using divariant solid-solution assemblages, Amer. Mineral., 63, 511-515, 1978.

Ziegenbein, D., and W. Johannes, Gaschromatographic analysis of experimental high pressure hydrothermal fluids, Neues. Jahrb. Mineral. Mont. , 130, 145-149, 1977.

\section{General Physical Chemistry}

Anderson, G. M. , Error propagation by the Monte Carlo method in geochemical calculations, Geochim. Cosmochim. Acta, 40, 1533-1538, 1976.

Anderson, G. M., Thermodynamics and sulfide solubilities, in Application of Thermodynamics to Petrology and Ore Deposits, edited by H. J. Greenwood, pp. 136-150, Mineralogical Association of Canada, Vancouver, 1977a.

Anderson, G. M., Uncertainties in calculations involving thermodynamic data, in Application of Thermodynamics to Petrology and Ore Deposits, edited by H. J. Greenwood, pp. 199215, Mineralogical Association of Canada, Vancouver, 1977b.

Cantor, S., Entropy estimates of garnets and other silicates, Science, 198, 206-207, 1977.

Charlu, T. V., R. C. Newton, and 0. J. Kleppa, Enthalpies of formation at $970 \mathrm{~K}$ of compounds in the system $\mathrm{MgO}-\mathrm{Al}_{2} \mathrm{O}_{3}-\mathrm{SiO}_{2}$ from high temperature solution calorimetry, Geochim. Cosmochim. Acta, 39, 1487-1498, 1975.

Charlu, T. V., R. C. Newton, and 0. J. Kleppa, Enthalpy of formation of some lime silicates by high-temperature solution calorimetry, with discussion of high pressure phase equilibria, Geochim. Cosmochim. Acta, 42, 367-376, 1978.

Chatterjee, N. D., Calculation of phase diagrams using thermochemical data derived from experimental studies of phase equilibria, Fortschr. Mineral., 52, 47-60, 1975.

Chatterjee, N. D., Thermodynamics of dehydration equilibria, in Thermodynamics in Geology, edited by D. J. Fraser, Pp. 137-159, D. Re1del Publishing Company, Dordrecht-Holland, 1977.

Chen, C.-H., A method of estimation of standard free energies of formation of silicate minerals at $298.15^{\circ} \mathrm{K}$, Amer. J. Sci. , 275, 801-817, 1975.

Crerar, D. A., A method for computing multicomponent chemical equilibria based on equilibrium constants, Geochim. Cosmochim。Acta, 39, 1375-1384, 1975.

Delany, J. M., and H. C. Helgeson, Calculation of the thermodynamic consequences of dehydration in subducting oceanic crust to $100 \mathrm{~kb}$ and > $800^{\circ} \mathrm{C}$, Amer. J.' Sc1., 278, 638-686, 1978.

Dibble, W. E., and F. W. Dickson, The influence of fluorine on the thermodynamic stability of sheet silicates, EOS, 59, 1218, 1978.

Eugster, H. P., Compositions and thermodynamics of metamorphic solutions, in Thermodynamics in Geology, edited by D. J. Fraser, pP. 183-202,
D. Reidel Publishing Company, DordrechtHolland, 1977.

Fraser, D。G., Thermodynamics in Geology, D. Reidel, Holland, 410 pp., 1977.

Froese, E., Applications of thermodynamics in metamorphic petrology, Geol. Survey of Canada, Paper 75-43, 37 Pp., 1976.

Greenwood, H. J., Thermodynamically valid projections of extensive phase relationships, Amer. Mineral., 60, 1-8, 1975.

Greenwood, H. J., editor, Application of Thermodynamics to Petrology and Ore Deposits, Mineralogical Association of Canada, 231 pp., 1977.

Gordon, T., Derivation of Internally conststent thermochemical data from phase equilibrium experiments using linear programming, in Application of Thermodynamics to Petrology and Ore Deposits, edited by H. J. Greenwood, PP. 185-198, Mineralogical Association of Canada, Vancouver, 1977.

Haas, J. L., Jr., and J. R. Fisher, Simultaneous evaluation and correlation of thermodynamic data, Amer. J. Sci., 276, 525-545, 1976.

Helgeson, H. C., Theoretical calculation of the thermodynamics of equilibrium and mass transfer among minerals and aqueous solutions at high pressures and temperatures, Geol. Soc. Amer. Abstracts with Programs, 10, 418, 1978.

Helgeson, H. C., and D. H. Kirkham, Theoretical prediction of the thermodynamic properties of aqueous electrolytes at high pressures and temperatures. III. Equation of state for aqueous species at infinite dilution. Amer. J. Sci., 276, 97-240, 1976.

Helgeson, H. C., J. M. Delany, H. W. Nesbitt, and D. K. Bird, Summary and critlque of the thermodynamic properties of rock-forming minerals, Amer. J. Sci., 278-A, 1-229, 1978.

Hemingway, B. S., and R. A. Robie, Enthalpies of formation of low albite ( $\operatorname{NaAlS}_{3} \mathrm{O}_{8}$ ), gibbsite $\left(\mathrm{Al}(\mathrm{OH})_{3}\right)$, and $\mathrm{NaAlO}_{2}$; revised values for $\Delta \mathrm{H}_{f}^{\circ}, 298$ and $\Delta \mathrm{G}_{f}^{\circ}, 298$ of some aluminosilicate minerals, J. Res. U. S. Geol. Survey, $\underline{5}$, 413429, 1977.

Hemingway, B. S., R. A. Robie, J. R. Fisher, and W. H. Wilson, Heat capacities of gibbsite, $\mathrm{Al}(\mathrm{OH})_{3}$ between 13 and $480 \mathrm{~K}$ and magnesite, $\mathrm{MgCO}_{3}$, between 13 and $380 \mathrm{~K}$ and their standard entropies at $289.15 \mathrm{~K}$, and the heat capacities of calorimetry conference benzolc acid between 12 and $316 \mathrm{~K}, \mathrm{~J}$. Res. U. S. Geol. Survey, $\underline{5}$, 797-806, 1977.

Hemingway, B. S., R. A. Robie, and J. A. Kittrick, Revised values for the Gibbs free energy of formation of $[\mathrm{Al}(\mathrm{OH}) \overline{4} \mathrm{aq}]$, diaspore, boehmite and bayerite at $298.15 \mathrm{~K}$ and 1 bar, the thermodynamic properties of kaolinite to $800 \mathrm{~K}$ and 1 bar, and the heats of solution of several gibbsite samples, Geochim. Cosmochim. Acta, 42, 1533-1544, 1978 .

Holloway, J. R., Fugacity and activity of molecular species in supercritical fluids, in Thermodynamics in Geology, edited by D. J. Fraser, pp. 161-181, D. Reidel Publishing Company, Dordrecht-Holland, 1977.

Holloway, J. R., and H. W. Westrich, A modified Redlich-Kwong equation for HF, EOS, 59, 1218, 1978.

Holst, N. B., Jr., The use of thermodynamic excess functions in the Nernst distribution 
law, Amer. Mineral., 63, 83-86, 1978.

Hovis, G. L., and D. R. Waldbaum, A solution calorimetric investigation of $\mathrm{K}-\mathrm{Na}$ mixing in a sanidine-analbite ion-exchange serles, Amer. Mineral., 62, 680-686, 1977.

Kerrick, D. M., and L. S. Darken, Statistica1 thermodynamic models for ideal oxide and silicate solid solutions, with application to plagioclase, Geochim. Cosmoch1m. Acta, $\underline{39}$, 1431-1442, 1975.

Kerrick, D. M., and G. K. Jacobs, Experimental and thermodynamic analysis of decarbonation equilibria in $\mathrm{P}-\mathrm{T}-\mathrm{X}_{\mathrm{CO}_{2}}$ space, EOS, $\underline{59}, 402$, 1978.

Kerrick, D. M., and J. Slaughter, Comparison of methods for calculating and extrapolating equilibria in P-T-X $\mathrm{CO2}$ space, Amer. J. Sci., 276, 883-916, 1976.

King, E. G., M. J. Ferrante, and L. B. Pankratz, Thermodynamic data for $\mathrm{Mg}(\mathrm{OH})_{2}$ (brucite), U.S. Bur. Mines Rept. Inv. 8041, 13 pp., 1975.

Kiseleva, I. A., Thermodynamic parameters of natural ordered sapphirine and synthetic disordered specimens, Geochem. International, $13,113-122,1976 a$.

Kiseleva, I. A., Thermodynamic properties and stability of pyrope, Geochem. International, $13,139-146,1976 \mathrm{~b}$.

Kiseleva, I. A., Gibb's free energy of formation of calcium garnets, Geochem. International, 14, 46-55, 1977.

Kiseleva, I. A., and N. D. Topor, Determination of enthalpy of solution of natural garnets by Calvet's high-temperature microcalorimetry, Geochem. Internationa1, 13, 96-98, 1976.

Kleppa, 0. J., and R. C. Newton, The role of solution calorimetry in the study of mineral equilibria, Fortschr. Mineral., 52, 3-20, 1975.

Kolesnik, Yu. N., N. V. Nogteva, v. N. Naumov, V. I. Butenko, and I. E. Paukov, Thermodynamic functions of gedrite and some equilibria in which it participates, Geochem. International, 13, 89-95, 1976.

Kolesnik, Yu. N., N. V. Nogteva, and I. Ye. Paukov, The specific heat of pyrope at $13-300^{\circ} \mathrm{K}$ and the thermodynamic parameters of some natural varleties of garnet, Geochem. International, 14, $126-133,1977$.

Mueller, R. F., and S. K. Saxena, Chemical Petrology, Springer-Verlag, New York, 394 pp., 1977.

Navrotsky, A., Thermochemistry of chromium compounds, especially oxides at high temperature, Geochim. Cosmochim. Acta, 39, 819-832, 1975.

Navrotsky, A., and W. E. Coons, Thermochemistry of some pyroxenes and related compounds, Geochim. Cosmochim. Acta, 40, 1281-1288, 1976.

Navrotsky, A., and R. B. Kasper, Spinel disproportionation at high pressure: calorimetric determination of enthalpy of formation of $\mathrm{Mg}_{2}$ $\mathrm{SnO}_{4}$ and $\mathrm{Co}_{2} \mathrm{SnO}_{4}$ and some implications for silicates, Earth P1anet. Sci. Lett., 31, 247$254,1976$.

Navrotsky, A., and D. Loucks, Calculation of subsolidus phase relations in carbonates and pyroxenes, Phys. Chem. Minerals, 1, 109-127, 1977.

Nesbitt, H. W., Estimation of the thermodynamic properties of $\mathrm{Na}-\mathrm{Ca}$ and $\mathrm{Mg}$-beidellites, Can. Minera1., 15, 22-29, 1977.
Newton, R. C., T. V. Charlu, and 0. J. Kleppa, Thermochemistry of high pressure garnets and clinopyroxenes in the system $\mathrm{CaO}-\mathrm{MgO}-\mathrm{Al}_{2} \mathrm{O}_{3}-$ $\mathrm{SiO}_{2}$, Geochim. Cosmochim. Acta, 41, 369-378, 1977 .

Openshaw, R. E., B. S. Hemingway, R. A. Robie, D. R. Waldbaum, and K. M. Krupka, The heat capacities at low temperatures and entropies at $298.15 \mathrm{~K}$ of low albite, microcline, and high sanidine, J. Res. U. S. Geol. Survey, 4, 195-204, 1976.

Perkins, D., III, E. J. Essene, E. F. Westrum, Jr., and V. J. Wall, Application of new thermodynamic data to grossular phase relations, Contr. Mineral. Petrol., 64, 137-147, 1977.

Powell, R., Equilibrium Thermodynamics in Petrology, Harper and Row, London, 284 pp. , 1978.

Robie, R. A., B. S. Hemingway, and W. H. Wilson, The heat capacities of calorimetry conference copper and of muscovite $\mathrm{KAl}_{2}\left(\mathrm{AlSi}_{3}\right) \mathrm{O}_{10}(\mathrm{OH})_{2}$, pyrophyllite $\mathrm{Al}_{2} \mathrm{Si}_{4} \mathrm{O}_{10}(\mathrm{OH})_{2}$, and illite $\mathrm{K}_{3}$ $\left(\mathrm{Al}_{7} \mathrm{Mg}\right)\left(\mathrm{SI}_{14} \mathrm{Al}_{2}\right)_{40}(\mathrm{OH})_{8}$ between 15 and $375 \mathrm{~K}$ and their standard entropies at $298.15 \mathrm{~K}$, J. Res. U. S. Geo1. Survey, 4, 631-644, 1976.

Robie, R. A., B. S. Hemingway, and J. R. Fisher, Thermodynamic properties of minerals and related substances at $298.15 \mathrm{~K}$ and 1 bar $\left(10^{5}\right.$ Pascals) pressure and at higher temperatures, U. S. Geol. Surv. Bull., 1452, 456 PP., 1978.

Roble, R. A., B. S. Hemingway, and W. H. Wilson, Low-temperature heat capacities and entropies of feldspar glasses and of anorthite, Amer. Mineral., 63, 109-123, 1978.

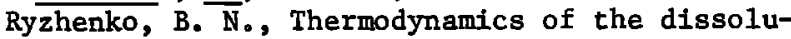
tion of inorganic substances in hot aqueous solutions, Geochem. International, 13, 139-153, 1976.

Saxena, S. K., Entropy estimates for some silicates at $298^{\circ} \mathrm{K}$ from molar volumes, Sclence, 193, 1241-1242, 1976.

Shmulovich, K. I., and V. M. Shmonov, Fugacity coefficients for $\mathrm{CO}_{2}$ from 1.0132 to 10,000 bar and $450-1300^{\circ} \mathrm{K}$, Geochem. International, 12 , 202-206, 1975.

Skippen, G. B., Thermodynamics of experimental sub-solidus sillcate systems including mixed volatiles, Fortschr. Mineral., 52, 75-99, 1975.

Skippen, G. B., Dehydration and decarbonation equilibria, in Application of Thermodynamics to Petrology and Ore Deposits, edited by $\mathrm{H}$. J。 Greenwood, pp. 66-83, Mineralogical Assoclation of Canada, Vancouver, 1977.

Skippen, G. B., and D. M. Carmichael, Mixedvolatile equilibria, in Application of thermodynamics to Petrology and Ore Deposits. edited by H. J. Greenwood, pp. 109-125, Mineralogical Association of Canada, Vancouver, 1977.

Slaughter, J。, V. J. Wa11, and D. M. Kerrick, APL computer programs for thermodynamic calculations of equilibria in $\mathrm{P}-\mathrm{T}-\mathrm{X}_{\mathrm{CO}}$ space, Contr. Minera1. Petrol., 54, 157-171, 1976.

Sykes, M. L., J. R. Holloway, and A. D。 Eichon, Self-consistent entropy from the modified Redlich-Kwong equation: $\mathrm{H}_{2} \mathrm{O}, \underline{\mathrm{EOS}}, \underline{59}, 1218$, 1978.

Tardy, Y., and R. M. Garrels, Prediction of Gibbs energies of formation - I. Relationships among Gibbs energies of formation of hydroxides, 
oxides and aqueous ions, Geochim. Cosmochim. Acta, 40, 1051-1056, 1976.

Tardy, Y., and R. M. Garrels, Prediction of Gibbs energies of formation of compounds, from the elements - II. Monovalent and divalent metal silicates, Geochim。Cosmochim。Acta, 41, 87-92, 1977.

Tardy, Y., and L. Gartner, Relationships among Gibbs energies of formation of sulfates, nitrates, carbonates, oxides and aqueous ions, Contr. Mineral. Petrol., 63, 89-102, 1977.

Tardy, Y., and P. Vieillard, Relationships among Gibbs free energies and enthalpies of formation of phosphates, oxides and aqueous ions, Contr. Mineral. Petro1., 63, 75-88, 1977.

Thompson, A. B., D. Perkins, III, U. Sonderegger, and R. C. Newton, Heat capacities of synthetic $\mathrm{CaAl}_{2} \mathrm{SiO}_{6}-\mathrm{CaMgSi}_{2} \mathrm{O}_{6}-\mathrm{Mg}_{2} \mathrm{Si}_{2} \mathrm{O}_{6}$ pyroxenes, EOS, $\underline{59}$, $395,1978$.

Ulbrich, H. H., and D. R. Waldbaum, Structural and other contributions to the third-1aw entropies of silicates, Geochim. Cosmochim. Acta, 40, 1-24, 1976.

Walther, J. V., and H. C. Helgeson, Calculation of the thermodynamic properties of aqueous silica and the solubility of quartz and its polymorphs at high pressures and temperatures, Amer. J. Sci. , 277, 1315-1351, 1977.

Westrich, H. R., and J. R. Holloway, Activity of $\mathrm{HF}$ in supercritical $\mathrm{HF}-\mathrm{H}_{2} \mathrm{O}$ fluids, EOS, $\underline{59}$, 1218, 1978.

Wood, B. J., The application of thermodynamics to some subsolidus equilibria involving solid solutions, Fortschr. Mineral., 52, 21-45, 1975.

Wood, B. J., and D. G. Fraser, Elementary Thermodynamics for Geologists, Oxford University Press, London, 301 pp., 1976.

Wood, B. J., and J. Nicho1ls, The thermodynamic properties of reciprocal solid solutions, Contr. Mineral. Petrol., 66, 389-400, 1978.

Zen, E-an, The phase-equilibrium calorimeter, the petrogenetic grid, and a tyranny of numbers, Amer. Mineral., 62, 189-204, 1977.

Zen, E-an, and J. V. Chernosky, Jr., Correlated free energy values of anthophyllite, brucite, clinochrysotile, enstatite, forsterite, quartz, and talc, Amer. Minera1., 61, 1156-1166, 1976.

\section{Ortho and Ring Silicates}

Abs-Wurmbach, I., and K. Langer, Synthetic $\mathrm{Mn}^{3+}-$ kyanite and viridine, $\left(\mathrm{Al}_{2-\mathrm{x}^{\mathrm{Mn}}}{ }_{\mathrm{X}}^{+}\right) \mathrm{SiO}_{5}$, in the system $\mathrm{Al}_{2} \mathrm{O}_{3}-\mathrm{MnO}-\mathrm{MnO}_{2}-\mathrm{SiO}_{2}$, Contr. Mineral. Petrol., 49, 21-38, 1975.

Ackermand, D., F. Seifert, and W. Schreyer, Instability of sapphirine at high pressures, Contr. Mineral. Petro1., 50, 79-92, 1975.

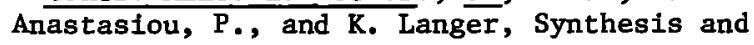
physical properties of piemontite $\mathrm{Ca}_{2} \mathrm{Al}_{3-p}$ $\mathrm{Mn}_{\mathrm{p}}^{3}\left(\mathrm{Si}_{2} \mathrm{O}_{7} / \mathrm{SiO}_{4} / \mathrm{OH}\right)$, Contr. Mineral. Petrol., 60, 225-245, 1977.

Anderson, P. A. M., R. C. Newton, and 0. J. Kleppa, The enthalpy change of the andalusitesillimanite reaction and the $\mathrm{Al}_{2} \mathrm{SiO}_{5}$ diagram, Amer. J. Sci., 277, 585-593, 1977.

Bishop, F. C., and R. C. Newton, The composition of low-pressure synthetic sapphirine, J. Geol., 83, 511-517, 1975.

Cressey, G., R. Schmid, and B. J. Wood, Thermodynamic properties of almandine-grossular garnet solid solutions, Contr. Mineral. Petrol., 67, 397-404, 1978.

Engi, M., Olivine-spinel geothermometry: An experimental study of the magnesium-iron exchange, EOS, 59, 401, 1978.

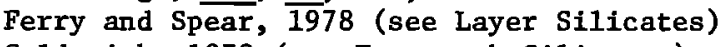
Goldsmith, 1978 (see Framework Silicates)

Hensen, B. J., The stability of pyrope-grossular garnet with excess silica, Contr. Mineral. Petrol., 55, 279-292, 1976.

Hensen, B. J., The stability of osumilite in high grade metamorphic rocks, Contr. Mineral. Petro1., 64, 197-204, 1977.

Hensen, B. J., R. Schmid, and B. J. Wood, Activity-composition relationships for pyropegrossular garnet, Contr. Mineral. Petro1., 51, 161-166, 1975.

Hsu, L. C., The phase relationships in the system $\mathrm{Ca}_{3} \mathrm{Al}_{2} \mathrm{Si}_{3} \mathrm{O}_{12}-\mathrm{Mn}_{3} \mathrm{Al}_{2} \mathrm{Si}_{3} \mathrm{O}_{12}-\mathrm{H}_{2} \mathrm{O}$ at 2.0 kilobars, EOS, 59, $402,1978$.

Huckenholz, H. G., Uvarovite stability in the $\mathrm{CaSiO}_{3}-\mathrm{Cr}_{2} \mathrm{O}_{3}$ join up to $10 \mathrm{kbar}$, Carnegie Inst. Wash. Yearb. , 74, 446-453, 1975a.

Huckenholz, H. G., Uvarovite stability in the $\mathrm{CaSlO}_{3}-\mathrm{Cr}_{2} \mathrm{O}_{3}$ join up to $10 \mathrm{kbar}$, Neues. Jahrb. Mineral. Mont., 3, 337-360, 1975b.

Huckenholz, H. G., Gehlenite stability relations in the join $\mathrm{Ca}_{2} \mathrm{Al}_{2} \mathrm{SiO}_{7}-\mathrm{H}_{2} \mathrm{O}$ up to $10 \mathrm{kbar}$, Neues. Jahrb. Mineral. Mont. , 130, 169-186, 1977.

Huckenholz, H. G., and D. Knittel, Uvarovite: Stability of uvarovite-grossularite solid solution at low pressure, Contr. Mineral. Petro1., 49, 211-232, 1975.

Huckenholz, $\vec{H}$. G., and D. Knittel, Uvarovite: Stability of uvarovite-andradite solid solutions at low pressure, Contr. Mineral. Petro1., 56, 61-76, 1976.

Huckenholz, H. G., E. Hö1z1, and W. Lindhuber, Grossularite, its solidus and liquidus relations in the $\mathrm{CaO}-\mathrm{Al}_{2} \mathrm{O}_{3}-\mathrm{SiO}_{2}-\mathrm{H}_{2} \mathrm{O}$ system up to $10 \mathrm{kbar}$, Neues. Jahrb. Mineral. Mont., 124, $1-46,1975$.

Hunt, J. A., and D. M. Kerrick, The stability of sphene: experimental redetermination and geologic implications, Geochim. Cosmochim. Acta, 41, 279-288, 1977.

$\mathrm{Krogh}, \mathrm{E}$. J., and A. Răheim, Temperature and pressure dependence of $\mathrm{Fe}-\mathrm{Mg}$ partitioning between garnet and phengite, with particular reference to eclogites, Contr. Mineral. Petrol., 66, 75-80, 1978 .

Rosenberg, P. E., Fluorine-hydroxyl exchange in topaz, EOS, 59, 1218, 1978.

Schiffman, P., and P. M. Fenn, Synthesis of coarse-grained prehnite and pumpellyite through alteration of synthetic basaltic mineral aggregates at 7-9 kb fluid pressure, Geol. Soc. Amer. Abstracts with Programs, $10,485,1978$.

Schneider, G., Experimental replacement of garnet by biotite, Neues. Jahrb. Mineral. Mont., 1, $1-10,1975$.

Seifert, F., Boron-free konnerupine: a highpressure phase, Amer. J. Sci., 275, 57-87, 1975.

Shmulovich, K. I., Stability limits of grossular and wollastonite in the $\mathrm{H}_{2} \mathrm{O}-\mathrm{CO}_{2}$ system up to $6 \mathrm{kbar}$, Geochem. International, 14, 126-134, 1977 。

Taylor, B. E., and J. G. Liou, The low-temperature stability of andradite in $\mathrm{C}-\mathrm{O}-\mathrm{H}$ fluids, Amer. Mineral., 63, 378-393, 1978.

Werding, G., and W. Schreyer, Synthesis and 
crystal chemistry of kornerupine in the system MgO- $\mathrm{Al}_{2} \mathrm{O}_{3}-\mathrm{SiO}_{2}-\mathrm{B}_{2} \mathrm{O}_{3}-\mathrm{H}_{2} \mathrm{O}$, Contr. Mineral. Petrol., 67, 247-260, 1978 .

Wood, B. J., Experimental determination of the mixing properties of solid solutions with particular reference to garnet and clinopyroxene solutions, in Thermodynamics in Geology, edited by D. J. Fraser, Pp. 11-27, D. Reidel Publishing Company, DordrechtHolland, 1977.

\section{Chain Silicates}

Abrecht, J., and Tj. Peters, Hydrothermal synthesis of pyroxenoids in the system $\mathrm{MnSiO}_{3}-\mathrm{CaSiO}_{3}$ at $P_{f}=2 \mathrm{~kb}$, Contr. Mineral. Petrol., $\underline{50}$, $241-246,1975$.

Bohlen, S. R., and A. L. Boettcher, The effect of manganese on orthopyroxene-olivine-quartz stability: orthopyroxene geobarometry, Geol. Soc. Amer. Abstracts with Programs, 10, $\overline{369}$, 1978.

Bohlen, S. R., A. L. Boettcher, and E. J. Essene, Experimental reinvestigation of ferrosilitefayalite-quartz stability, EOS, 59, 402, 1978.

Braue, W., and H. A. Seck, Stability of pargasiterichterite solid solutions at $1 \mathrm{~kb}$ water vapor pressure, Neues. Jahrb. Mineral. Mont., 130, $19-32,1977$.

Cameron, K. L., An experimental study of actinolite-cummingtonite phase relations with notes on the synthesis of Fe-rich anthophyllite, Amer. Mineral., 60, 375-390, 1975.

Charles, R. W., The phase equilibria of richterite and ferrorichterite, Amer. Mineral. , 60, 367374,1975 。

Charles, R. W., The phase equilibria of intermediate compositions on the pseudobinary $\mathrm{Na}_{2} \mathrm{CaMg}_{5} \mathrm{Si}_{8} \mathrm{O}_{22}(\mathrm{OH})_{2}-\mathrm{Na}_{2} \mathrm{CaFe}_{5} \mathrm{Si}_{8} \mathrm{O}_{22}(\mathrm{OH})_{2}$, Amer. J. Sc1. , 277, 594-625, 1977.

Charles, R. W. , Synthesis and stability of hastingsite: $\mathrm{Ca}_{2} \mathrm{NaFe}_{5} \mathrm{Fe}^{3+} \mathrm{Si}_{5} \mathrm{Al}_{2} \mathrm{O}_{22}(\mathrm{OH})_{2}$, EOS, 59, 1217, 1978.

Chernosky, J. V., Jr., The stability of anthophyllite--A reevaluation based on new experimental data, Amer. Mineral., 61, 1145-1155, 1976.

Drysdale, D. J., Hydrothermal synthesis of various spodumenes, Amer. Mineral., 60, 105-110, 1975.

Fonarev, V. I., G. Ya. Korol'kov, and T. N. Dokina, Stability of the cummingtonite-quartzmagnet1te association, Geochem. International, $13,34-45,1976 a$.

Fonarev, V. I., G. Ya. Korol'kov, and T. N. Dokina, Stability of the orthopyroxene + magnetite + quartz association under hydrothermal conditions, Geochem. International, 13, $134-146,1976 \mathrm{~b}$.

Forbes, W. C., Stability relations of grunerite, $\mathrm{Fe}_{7} \mathrm{Si}_{8} \mathrm{O}_{22}(\mathrm{OH})_{2}$, Amer. J. Sci., 277, 735-749, 1977.

Gunter, W. D., and H. P. Eugster, Wollastonite solubility and free energy of supercritical aqueous $\mathrm{CaCl}_{2}$, Contr. Mineral. Petro1., 66, 271-281, 1978 .

Herzberg, C. T., Pyroxene geothermometry and geobarometry: experimental and thermodynamic evaluation of some subsolidus phase relations involving pyroxenes in the system $\mathrm{CaO}-\mathrm{MgO}-$
$\mathrm{Al}_{2} \mathrm{O}_{3}-\mathrm{SiO}_{2}$, Geochim. Cosmochim. Acta, 42, 94b$958,1978$.

Hinrichsen, Th., and K. Schürmann, Experimental investigations on the $\mathrm{Na} / \mathrm{K}$-substitution in edenites and pargasites, Neues. Jahrb. Mineral. Mont. , 130, 12-18, 1977.

Ikeda, K., and K. Yagi, Experimental study on the phase equilibria in the join $\mathrm{CaMgSi}_{2} \mathrm{O}_{6}-\mathrm{CaCrCr}$ $\mathrm{SiO}_{6}$ with special reference to the blue diopside, Contr. Mineral. Petrol., 61, 91-106, 1977.

Lindsley, D. H., and S. A. Dixon, Diopsideenstatite equilibria at $850^{\circ}$ to $1400^{\circ} \mathrm{C}, 5$ to $35 \mathrm{~kb}$, Amer. J. Sci., 276, 1285-1301, 1976.

Loida, V. A., and Th. Hinrichsen, Synthesis and stability relations of granulitic amphiboles, Neues. Jahrb. Mineral. Mont., 1, 45-47, 1975.

Maresch, W. V., Experimental studies on glaucophane: an analysis of present knowledge, Tectonophysics, 43, 109-126, 1977.

Maresch, W. V., and K. Langer, Synthesis, lattice constants and $\mathrm{OH}$-valence vibrations of an orthorhombic amphibole with excess $\mathrm{OH}$ in the system $\mathrm{Li}_{2} \mathrm{O}-\mathrm{MgO}-\mathrm{SiO}_{2}-\mathrm{H}_{2} \mathrm{O}$, Contr. Mineral. Petrol. , 56, 27-34, 1976.

Maresch, W. V., and A. Mottana, The pyroxmangiterhodonite transformation for the $\mathrm{MnSiO}_{3}$ composition, Contr. Mineral. Petro1., 55, 69-79, 1976.

McCallister, R. H., and R. A. Yund, Coherent exsolution in Fe-free pyroxenes, Amer. Mineral., 62, $721-726,1977$.

McKinstry, B., and G. Skippen, An experimental study of the stability of tremolite, Geol. Soc. Amer. Abstracts with Programs, $1 \overline{0}, 454$, 1978.

Metz, P., Experimental investigation of the metamorphism of siliceous dolomites. III. Equilibrium data for the reaction: 1 tremolite +11 dolomite $\rightleftharpoons 8$ forsterite +13 calcite + $9 \mathrm{CO}_{2}+1 \mathrm{H}_{2} \mathrm{O}$ for the total pressures of 3,000 and 5,000 bars, Contr. Mineral. Petrol., 58, 137-148, 1976.

Mori, T., Experimental study of pyroxene equilibrla in the system of $\mathrm{CaO}-\mathrm{MgO}-\mathrm{FeO}-\mathrm{SiO}_{2}, \mathrm{~J}$. Petrol., 19, 45-65, 1978.

Popp, R. K., M. C. Gilbert, and J. R. Craig, Synthesis and X-ray properties of Fe-Mg orthoamphiboles, Amer. Mineral., 61, 12671279,1976 。

Popp, R. K., M. C. Gllbert, and J. R. Craig, Stability of $\mathrm{Fe}-\mathrm{Mg}$ amphiboles with respect to oxygen fugacity, Amer. Minera1., 62, 1-12, $1977 a$.

Popp, R. K., M. C. Gilbert, and J. R. Craig, Stability of Fe-Mg amphiboles with respect to sulfur fugacity, Amer. Mineral. , 62, 13-30, $1977 \mathrm{~b}$.

Rajamani, V., Distribution of iron, cobalt, and nickel between synthetic sulfide and orthopyroxene at $900^{\circ} \mathrm{C}$, Econ. Geol., 71, 795-802, 1976.

Ravior, E., and Th. Hinrichsen, Upper stability of synthetic anthophyllite mixed crystals, Neues. Jahrb. Mineral. Mont. , 4, 162-166, 1975.

Seifert, F., Equilibrium $\mathrm{Mg}-\mathrm{Fe}{ }^{2+}$ cation distribution in anthophyllite, Amer. J. Sci. 1323-1333, 1978.

Selfert, F., and D. Virgo, Kinetics of the $\mathrm{Fe}^{2+}$ $\mathrm{Mg}$, order-disorder reaction in anthophyllites: quantitative cooling rates, Science, 188 , 1107-1109, 1975.

Tateyama, H., S. Shimoda, and T. Sudo, Synthesis 
and crystal structure of a triple chain silicate, $\mathrm{Na}_{2} \mathrm{Mg}_{4} \mathrm{Si}_{6} \mathrm{O}_{16}(\mathrm{OH})_{2}$, Contr. Mineral. Petrol., 66, 149-156, 1978.

Veblen, D. R., and C. W. Burnham, New biopyriboles from Chester, Vermont: I. Descriptive mineralogy, Amer. Mineral., 63, 1000-1009, 1978.

Wood, B. J., Reactions involving anorthite and $\mathrm{CaAl}_{2} \mathrm{SiO}_{6}$ pyroxene at high pressures and temperatures, Amer. J. Sci., 278, 930-942, 1978.

\section{Layer Silicates}

Baronnet, A., and B. Velde, Iron content of synthetic phlogopite as a function of growth rate, Earth Planet. Sci. Lett., 37, 150-153, 1978.

Blencoe, J. G., Molal volumes of synthetic paragonite-muscovite micas, Amer. Mineral., 62, 1200-1215, 1977.

Chatterjee, N. D., Margarite stability and compatibility relations in the system $\mathrm{CaO}-$ $\mathrm{Al}_{2} \mathrm{O}_{3}-\mathrm{SiO}_{2}-\mathrm{H}_{2} \mathrm{O}$ as a pressure-temperature indicator, Amer. Mineral., 61, 699-709, 1976.

Chatterjee, N. Do, and E. Froese, A thermodynamic study of the pseudobinary join muscoviteparagonite in the system $\mathrm{KAlSi}_{3} \mathrm{O}_{8}-\mathrm{NaAlSi}_{3} \mathrm{O}_{8}-$ $\mathrm{Al}_{2} \mathrm{O}_{3}-\mathrm{SiO}_{2}-\mathrm{H}_{2} \mathrm{O}$, Amer. Mineral., 60, 985-993, 1975.

Chernosky, J. V., Jr., Aggregate refractive Indices and unit cell parameters of synthetic serpentine in the system $\mathrm{MgO}-\mathrm{Al}_{2} \mathrm{O}_{3}-\mathrm{SiO}_{2}-\mathrm{H}_{2} \mathrm{O}$, Amer. Mineral., 60, 200-208, 1975.

Chernosky, J. V., Jr., The stability of clinochlore + quartz at low pressure, Amer. Mineral., 63, 73-82, 1978.

Chernosky, J. V., Jro, The stability of lizardite, Geol. Soc. Amer. Abstracts with Programs, 10, $379,1978$.

Eber1, D., G. Whitney, and H. Khoury, Hydrothermal reactivity of smectite, Amer. Mineral., 63, 401-409, 1978.

Ferry, J. M., and F. S. Spear, Experimental calibration of the partitioning of $\mathrm{Fe}$ and $\mathrm{Mg}$ between biotite and garnet, Contr. Mineral. Petro1., 66, 113-117, 1978.

Fleming, P. D., and J. J. Fawcett, Upper stability of chlorite + quartz in the system MgO-FeO$\mathrm{Al}_{2} \mathrm{O}_{3}-\mathrm{SiO}_{2}-\mathrm{H}_{2} \mathrm{O}$ at $2 \mathrm{kbar}$ water pressure, Amer. Mineral.; 61, 1175-1193, 1976.

Franz, G., and E. Althaus, Experimental investigation on the formation of solid solutions in sodium - aluminium - magnesium micas, Neues. Jahrb. Mineral. Mont., 126, 233-253, 1976.

Hazen, R. M., and D. R. Wones, Predicted and observed compositional limits of trioctahedral micas, Amer. Mineral., 63, 885-892, 1978.

Hewitt, D. A., Stability of the assemblage phlogopite-calcite-quartz, Amer. Mineral., 60, 391-397, 1975.

Hewitt, D. A., and D. R. Wones, Physical properties of some synthetic Fe-Mg-A1 trioctahedral biotites, Amer. Mineral., 60, 854-862, 1975.

Hofmann, A. W., B. J. Giletti, J. R. Hinthorne, C. A. Andersen, and D. Comaford, Ion microprobe analysis of a potassium self-diffusion experiment in biotite, Earth Planet. Sci. Lett., 24, 48-52, 1975.

Irving, A. J., W.-L. Huang, and P. J. Wyllie, Phase relations of portlandite, $\mathrm{Ca}(\mathrm{OH})_{2}$ and brucite, $\mathrm{Mg}(\mathrm{OH})_{2}$ to 33 kilobars, Amer. J. Sci., 277, 313-321, 1977.
James, R. S. , A. C. Turnock, and J. J. Fawcett, The stability and phase relations of iron chlorite below $8.5 \mathrm{~kb} \mathrm{P}_{\mathrm{H}_{2} \mathrm{O}}$, Contr. Mineral. Petro1. , 56, 1-25, 1976.

Kalinin, D. V., and M. A. Shapovalova, Kinetics of pyrophyllite formation and the stability limits of the mineral, Geochem. International, $12,231-236,1975$.

McOnie, A. W., J. J. Fawcett, and R. S. James, The stability of intermediate chlorites of the clinochlore-daphnite series at 2 kbar $\mathrm{P}_{\mathrm{H}_{2} \mathrm{O}}$ Amer. Mineralo, 60, 1047-1062, 1975.

Moody, J. B., An experimental study on the serpentinization of Iron-bearing olivines, Can. Mineral., 14, 462-478, 1976.

Munoz, J. L, and S. Ludington, Fluorine-hydroxyl exchange in synthetic muscovite and its application to muscovite-biotite assemblages, Amer. Mineral., 62, 304-308, 1977.

olesch, $M_{0}$, Synthesis and solid solubility of trioctahedral brittle micas in the system $\mathrm{CaO}$ $\mathrm{MgO}-\mathrm{Al}_{2} \mathrm{O}_{3}-\mathrm{SiO}_{2}-\mathrm{H}_{2} \mathrm{O}$, Amer. Mineral. , 60, 188$199,1975$.

0lesch, M., and F. Seifert, Stability and phase relations of trioctahedral calcium brittle micas, J. Petro1., 17, 291-314, 1976.

Perrotta, A. Jo, and T. J. Garland, Low temperature synthesis of zinc-phlogopite, Amer. Minera1. , 60, 152-154, 1975.

Puhan, D., Experimental study of the reaction: dolomite $+\mathrm{K}$-feldspar $+\mathrm{H}_{2} \mathrm{O} \neq$ phlogopite + calcite $+\mathrm{CO}_{2}$ at the total gas pressures of 4000 and 6000 bars, Neues. Jahrb. Mineral. Mont. , 3, 110-127, 1978 .

Robert, J. L。, Phlogopite solid solutions in the system $\mathrm{K}_{2} \mathrm{O}-\mathrm{MgO}-\mathrm{Al}_{2} \mathrm{O}_{3}-\mathrm{SiO}_{2}-\mathrm{H}_{2} \mathrm{O}$, Chem. Geol., 17, $195-212,1976 \mathrm{a}$.

Robert, J. Lo, Titanium solubility in synthetic phlogopite solid solutions, Chem. Geol., 17, 213-228, 1976b.

Schreyer, W., and Th. Baller, Talc-muscovite: synthesis of a new high-pressure phyllosilicate asserablage, Neues. Jahrb. Mineral. Mont., 9, 421-425, 1977.

Schulien, S., Determination of the equilibrium constant and the enthalpy of reaction for the $\mathrm{Mg}^{2+}-\mathrm{Fe}^{2+}$ exchange between biotite and a salt solution, Fortschr. Mineral., 52, 133$139,1975$.

Staudigel, H., and W. Schreyer, The upper thermal stability of clinochore, $\mathrm{Mg}_{5} \mathrm{Al}\left[\mathrm{AlSi}_{3} \mathrm{O}_{10}\right](\mathrm{OH})_{8}$, at $10-35 \mathrm{~kb} \mathrm{P}_{\mathrm{H}_{2} \mathrm{O}}$, Contr. Mineral. Petrol., 61, $187-198,1977$.

Velde, B., Clays and Clay Minerals in Natural and Synthetic Systems, Elsevier, Amsterdam, 218 ppo, 1977.

Velde, B., High temperature or metamorphic vermiculites, Contr. Mineral. Petrol., 66, 319-323, 1978a.

Velde, B., Infrared spectra of synthetic micas in the series muscovite-MgAl celadonite, Amer. Mineral., 63, 343-349, 1978b.

Wones, D. R., and F. C. W. Dodge, The stability of phlogopite in the presence of quartz and diopside, in Thermodynamics in Geology, edited by D. J. Fraser, pp. 229-247, D. Reide1 Publishing Company, Dordrecht-Holland, 1977.

Yada, K., and K. Iishi, Growth and microstructure of synthetic chrysotile, Amer. Mineral., 62, 958-965, 1977. 


\section{Framework Silicates}

Blencoe, J. G., and G. A. Merkel, Calculated activity coefficients and thermodynamic excess propertles for high albite-sanidine feldspars at 2 kbar pressure, $600-700^{\circ} \mathrm{C}$, EOS, 59, 395, 1978.

Delbove, F., Excess gibbs energy of microclinelow albite alkali feldspars at $800^{\circ} \mathrm{C}$ and 1 bar, based on fused alkall bromide ion-exchange experiments, Amer. Mineral., 60, 972-984, 1975.

Ellis, D. E., Stability and phase equilibria of chloride and carbonate bearing scapolites at $750^{\circ} \mathrm{C}$ and 4000 bar, Geochim. Cosmochim. Acta, 42, 1271-1282, 1978.

Ferry, J. M., and J. G. Blencoe, Subsolidus phase relations in the nepheline-kalsilite system at $0.5,2.0$, and $5.0 \mathrm{kbar}$, Amer. Mineral., 63, 1225-1240, 1978.

Goldsmith, J. R., Scapolites, granulites, and volatiles in the lower crust, Geol. Soc. Amer. Bul1., 87, 161-168, 1976。

Goldsmith, J. R。, Experimental plagioclasezoisite phase relations, EOS, 59, 402, 1978.

Goldsmith, J. R。, and R. C. Newton, Scapoliteplagioclase stability relations at high. pressures and temperatures in the system $\mathrm{NaAlSi}_{3} \mathrm{O}_{8}-\mathrm{CaAl}_{2} \mathrm{Si}_{2} \mathrm{O}_{8}-\mathrm{CaCO}_{3}-\mathrm{CaSO}_{4}$, Amer. Mineral., 62, 1063-1081, 1977.

Goto, Y., Synthesis of clinoptilolite, Amer. Mineral., 62, 330-332, 1977.

Gupta, A. K., and N. D. Chatterjee, Synthesis, composition, thermal stability, and thermodynamic properties of bicchulite, $\mathrm{Ca}_{2}$ $\left[\mathrm{Al}_{2} \mathrm{SiO}_{6}\right](\mathrm{OH})_{2}$, Amer. Mineral., 63, 58-65, 1978.

Holdaway, M. J., and S. M. Lee, Fe-Mg cordierite stability in high-grade pelitic rocks based on experimental, theoretical and natural observations, Contr. Mineral. Petrol., 63, 175-198, 1977.

Hovis, G. L., Unit-ce11 dimensions and molar volumes for a sanidine-analbite ion-exchange series, Amer. Mineral., 62, 672-679, 1977.

Kay, S. M., Exsolution in potassium-calcium feldspars: experimental evidence and relationship to antiperthites and B $\phi g g i l d$ lamellae, Amer. Mineral., 63, 136-142, 1978.

Lee, S. M., and M. J. Holdaway, Cordierite breakdown under high-pressure hydrous conditions. A comment, Contr. Mineral. Petrol., 56, 289295, 1976.

Matsuhisa, Y., J. R. Goldsmith, and R. N. Clayton, Mechanisms of hydrothermal crystallization of quartz at $250^{\circ} \mathrm{C}$ and $15 \mathrm{kbar}$, Geochim. Cosmochim. Acta, 42, 173-182, 1978.

Newton, R.'C., and J. R. Goldsmith, Stability of the scapolite meionite $\left(3 \mathrm{CaAl}_{2} \mathrm{Si}_{2} \mathrm{O}_{2} \cdot \mathrm{CaCO}_{3}\right)$ at high pressures and storage of $\mathrm{CO}_{2}$ in the deep crust, Contr. Mineral. Petrol。, 49, 49-62, 1975.

Orville, P. M., Stability of scapolite in the system $\mathrm{Ab}-\mathrm{An}-\mathrm{NaCl}-\mathrm{CaCO}_{3}$ at $4 \mathrm{~kb}$ and $750^{\circ} \mathrm{C}$, Geochim. Cosmochim. Acta, 39, 1091-1106, 1975.

Puhan, 1978 (see Layer Silicates)

Seifert, F., Stability of the assemblage cordierite $+\mathrm{K}$ feldspar + quartz, Contr. Minera1. Petro1., 57, 179-185, 1976.

Sipling, P. J., and R. A. Yund, Experimental determination of the coherent solvus for sanidine-high albite, Amer. Minera1., 61, 897-906, 1976.

Windom, K. $E_{0}$, and A. Lo Boettcher, The effect of reduced activity of anorthite on the reaction grossular + quartz = anorthite + wollastonite: a model for plagioclase in the earth's lower crust and upper mantle, Amer. Mineral., 61, 889-896, 1976.

Wintsch, $R_{\circ} \bar{P}_{\circ}$, Solid-fluid equilibria in the system $\mathrm{KAlSi}{ }_{3} \mathrm{O}_{8}-\mathrm{NaAlSi}_{3} \mathrm{O}_{8}-\mathrm{Al}_{2} \mathrm{SiO}_{5}-\mathrm{SiO}_{2}-\mathrm{H}_{2} \mathrm{O}-$ HC1, J. Petro1., 16, 57-79, 1975.

Wood, 1978 (see Chain Silicates)

\section{Nonsilicates}

Arnold, R. G., and 0. P. Malik, The NiS-S system above $980^{\circ} \mathrm{C}-\mathrm{A}$ revision, Ekcon. Geology, 70, 176-182, 1975.

Candia, M. A. F., Tj. Peters, and J. V. Valarelli, The experimental investigation of the reactions $\mathrm{MnCO}_{3}+\mathrm{SiO}_{2}=\mathrm{MnSiO}_{3}+\mathrm{CO}_{2}$ and $\mathrm{MnSiO}_{3}+$ $\mathrm{MnCO}_{3}=\mathrm{Mn}_{2} \mathrm{SiO}_{4}+\mathrm{CO}_{2}$ in $\mathrm{CO}_{2} / \mathrm{H}_{2} \mathrm{O}$ gas mixtures at a total pressure of 500 bars, Contr. Mineral. Petrol., 52, 261-266, 1975.

Chang, L. L. Y., and S. H. Hoda, Phase relations In the system $\mathrm{PbS}-\mathrm{Cu}_{2} \mathrm{~S}-\mathrm{Bi}_{2} \mathrm{~S}_{3}$ and the stability of galenobismutite, Amer. Mineral., 62, 346$350,1977$.

Chatterjee, $M_{0}$, and $D_{0}$ Ganguli, Phase relationships in the system BeO-ZnO-SiO ${ }_{2}$, Neues. Jahrb. Mineral. Mont., 11, 518-526, 1975.

Chou, I.-M., Siderite decomposition as a function of temperature and pressure along the magnetitehematite buffer, EOS, 59, 402, 1978.

Crerar, D. A., and H. L. Barnes, Ore solution chemistry V. Solubilities of chalcopyrite and chalcocite assemblages in hydrothermal solution at $200^{\circ}$ to $350^{\circ} \mathrm{C}$, Econ. Geol., 71, 772-794, 1976.

Franz, E.-D., Synthetic solid solutions between goethite and diaspore, Minera1. Mago, 42, 159$160,1978$.

Friel, J. J., R. I. Harker, and G. C. Ulmer, Armalcolite stability as a function of pressure and oxygen fugacity, Geochim. Cosmochim. Acta, $41,403-410,1977$.

Froese, E., and A. E. Gunter, A note on the pyrrhotite-sulfur vapor equilibrium, Econ. Geol., 71, 1589-1594, 1976.

Froese, E, and A, E. Gunter, A note on the pyrrhotite-sulfur vapor equilibrium--a discussion, Econ. Geol., 73, 286, 1978。

Govett, G. J. S., W. D. Goodfellow, and R. E. S. Whitehead, Experimental aqueous dispersion of elements around sulfides, Econ. Geol., 71, 92-93, 1976.

Grandstaff, D. E., A kinetic study of the dissolution of uraninite, Econ. Geo1., 71, 1493-1506, 1976.

Grandstaff, D. E., A kinetic study of the dissolution of uraninite - A reply, Econ. Geol。, 72, 1361,1977

Habashi, F。, A kinetic study of the dissolution of uraninite - A discussion, Econ. Geol., 72, 1360,1977 .

Hoffman, E., and W. Ho Maclean, Phase relations of michenerite and merenskyite in the Pd-Bi-Te system, Econ. Geo1. , 71, 1461-1468, 1976.

Hsu, L. C., The stability relations of the wolframite series, Amer. Mineral., 61, 944955, 1976.

Jacobson, R. L., and H. E. Usdowski, Partitioning of strontium between calcite, dolomite and 
liquids: An experimental study under higher temperature diagenetic conditions, and a model for the prediction of mineral pairs for geothermometry, Contr. Mineral. Petro1., 59, 171-185, 1976.

Katz, A., and A. Matthews, The dolomitization of $\mathrm{CaCO}_{3}$ : an experimental study at $252-295^{\circ} \mathrm{C}$, Geochim. Cosmochim. Acta, 41, 297-308, 1977.

Kolonin, G. R., G. P. Shironosova, and Yu. V. Laptev, Experimental checking of thermodynamic diagrams of the stability of $\mathrm{W}, \mathrm{Mo}$, and $\mathrm{Bi}$ minerals under hydrothermal conditions, Fortschr. Mineral., 52, 161-167, 1975.

Kurepin, V. A., Component activities, thermodynamic characteristics of reactions, and phase equilibria in the Fe-0 system at high temperatures and pressures, Geochem. International, 12, $114-121,1975$.

Kusakabe, M., and B. W. Robinson, Oxygen and sulfur isotope equilibria in the $\mathrm{BaSO}_{4}-\mathrm{HSO}_{4}-\mathrm{H}_{2} \mathrm{O}$ system from 110 to $350^{\circ} \mathrm{C}$ and applications, Geochim. Cosmochim. Acta, 41, 1033-1040, 1977.

Lee, M. S., S. Takenouchi, and H. Imai, Syntheses of stannoidite and mawsonite and their genesis in ore deposits, Econ. Geo1., 70, 834-843, 1975.

Lindsley, D. H., Magnetite-ilmenite equilibria: Solution models including $\mathrm{MgO}$ and $\mathrm{MnO}$, EOS, 59 , $395,1978$.

Loh, S. E., and W. S.'Wise, Synthesis and fluorine-hydroxyl exchange in the amblyconite series, Can. Mineral., 14, 357-363, 1976.

Luce, F. D., C. L. Tuttle, and B. J. Skinrer, Studies of sulfosalts of copper: V. Phases and phase relations in the system $\mathrm{Cu}-\mathrm{Sb}-\mathrm{As}-\mathrm{S}$ between $350^{\circ}$ and $500^{\circ} \mathrm{C}$, Econ. Geol. , 72, 271$289,1977$.

Lusk, J., and C. E. Ford, Experimental extension of the sphalerite geobarometer to $10 \mathrm{kbar}$, Amer. Minera1., 63, 516-519, 1978.

Makovicky, E., and B. J. Skinner, Studies of the sulfosalts of copper. VI. Low-temperature exsolution in synthetic tetrahedrite solid solution, $\mathrm{Cu}_{12}{ }_{\mathrm{x}} \mathrm{Sb}_{4}+_{\mathrm{y}} \mathrm{S}_{13}$, Can. Mineral., 16, $611-623,1978$.

Mandziuk, Z. L., and S. D. Scott, Synthesis, stabllity, and phase relations of argentian pentlandite in the system $\mathrm{Ag}-\mathrm{Fe}-\mathrm{Ni}-\mathrm{S}$, Can. Mineral., 15, 349-364, 1977.

Marland, G., Phase equilibria in the system calcium carbonate-water, Geochim. Cosmochim. Acta, 39, 1193-1196, 1975.

Muan, A., Phase relations in chromium oxidecontaining systems at elevated temperatures, Geochim. Cosmochim. Acta, 39, 781-802, 1975.

Potter, R. W., II, An electrochemical investigation of the system copper-sulfur, Econ. Geol., 72, 1524-1542, 1977.

Potter, R. W., II, and H. L. Barnes, Phase relations in the binary $\mathrm{Hg}-\mathrm{S}$, Amer. Mineral., 63, 1143-1152, 1978.

Rajamani, V., 1976 (see Chain Silic:tes)

Sachdev, S. C., and L. L. Y. Chang, Phase relations in the system tin-antimony-lead sulfides and the synthesis of cylindrite and franckeite, Econ. Geo1., 70, 1111-1122, 1975.

Scott, S. D., Hydrothermal synthesis of refractory sulfide minerals, Fortschr. Mineral., 52, 185-195, 1975.

Simpson, D。 R., Aluminum phosphate variants of feldspar, Amer。 Mineral., 62, 351-355, 1977.

Skinner, B. J., F. D. Luce, J. A. Dill, D. E.
E1lis, H. A. Hagan, D. M. Lewis, D. A. Odell, D. A. Sverjensky, and N. Williams, Phase relations in the ternary portions of the system Pt-Pd-Fe-As-S, Econ. Geol., 71, 1469$1475,1976$.

Spencer, K. J., and D. H. Lindsley, New experimental results on the magnetite-ulvospinel $\left(\mathrm{Mt}_{\mathrm{ss}}\right.$ ) hematite-ilmenite ( $\mathrm{Ilm}_{\mathrm{ss}}$ ) solution model using the Co-CoO buffer, Geol. Soc. Amer. Abstracts with Programs, 10, 496, 1978.

Sugakf, A., H. Shima, A. Kitakaze, and H. Harada, Isothermal phase relations in the system $\mathrm{Cu}-$ Fe-S under hydrothermal conditions at $350^{\circ} \mathrm{C}$ and $300^{\circ} \mathrm{C}$, Econ. Geo1., 7.0, 806-823, 1975.

Suvorova, V. A., and A. S. Tenishev, An experimental study of equilibrium distribution of sulfur isotopes between $\mathrm{Mo}, \mathrm{Pb}, \mathrm{Zn}$ and $\mathrm{Sn}$ sulfides, Geochem. International, 13, 74-77, 1976.

Tatsuka, K., and N. Morimoto, Tetrahedrite stability relations in the $\mathrm{Cu}-\mathrm{Sb}-\mathrm{S}$ system, Econ. Geo1. , 72, 258-270, 1977.

Tatsuka, K., and N. Morimoto, Tetrahedrite stability relations in the $\mathrm{Cu}-\mathrm{Fe}-\mathrm{Sb}-\mathrm{S}$ system, Amer. Mineral., 62, 1101-1109, 1977.

Vorob'yeva, K. A., and Yu. P. Mel'nik, An experimental study of the system of $\mathrm{Fe}_{2} \mathrm{O}_{3}-\mathrm{H}_{2} \mathrm{O}$ at $\mathrm{T}=100-200^{\circ} \mathrm{C}$ and $\mathrm{P}$ up to 9 kilobars, Geochem. International, 14, 108-115, 1977.

Wang, N., Synthesis and crystal data of a $\mathrm{Cu}-$ free "meneghinite", Can. Mineral., 15, 115-116, 1977.

Wechsler, B. A., C. T. Prewitt, and J. J. Papike, Chemistry and structure of lunar and synthetic armalcolite, Earth. Planet. Sci. Lett., 29, 91-103, 1976 .

White, W. B., and R. Roy, The system chromiumoxygen at high oxygen pressures, Geochim. Cosmochim. Acta, 39, 803-818, 1975.

Wise, W. S.,. and S. E. Loh, Equilibria and origin of minerals in the system $\mathrm{Al}_{2} \mathrm{O}_{3}-\mathrm{AlPO}_{4}-$ $\mathrm{H}_{2} \mathrm{O}$, Amer. Mineral., 61, 409-413, 1976.

\section{Aqueous Solution Equilibria}

Blount, C. W., Barite solubilities and thermodynamic quantities up to $300^{\circ} \mathrm{C}$ and 1400 bars, Amer. Mineral. , 62, 942-957, 1977.

Crerar, D. A., N. J. Susak, M. Borcsik, and S. Schwartz, Solubility of the buffer assemblage pyrite + pyrrhotite + magnetite in $\mathrm{NaCl}$ solutions from 200 to $350^{\circ} \mathrm{C}$, Geochim. Cosmochim. Acta, 42, 1427-1438, 1978.

Ewers, G. W., Experimental hot water-rock interactions and their significance to natural hydrothermal systems in New Zealand, Geochim. Cosmochim. Acta, 41, 143-150, 1977.

Foster, R. P., Solubility of scheelite in hydrothermal chloride solutions, Chem. Geo1., 20, 27-44, 1977.

Fournier, R. 0., Exchange of $\mathrm{Na}^{+}$and $\mathrm{K}^{+}$between water vapor and feldspar phases at high temperature and low vapor pressure, Geochim. Cosmochim. Acta, 40, 1553-1562, 1976.

Frantz, J. D., and R. K. Popp, Determination of aqueous calcium speciation in the system: $\mathrm{CaO}-\mathrm{SiO}_{2}-\mathrm{H}_{2} \mathrm{O}-\mathrm{HCl}$, at $600^{\circ} \mathrm{C}, 2 \mathrm{kbar}, \underline{\mathrm{EOS}}$, 59, $1217,1978$.

Frantz, J. D., and R. K. Popp, An experimental study of complexing and thermodynamic properties 
of aqueous $\mathrm{MgCl}_{2}$ in the system $\mathrm{MgO}-\mathrm{SiO}_{2}-\mathrm{H}_{2} \mathrm{O}-\mathrm{HCl}$, Carnegie Inst. Wash. Yearb., 77, 812-822, 1978.

Frantz, J. D., and R. K. Popp, The Ionization constant of $\mathrm{HCl}$ as a function of temperature and pressure, Carnegie Inst. Wash. Yearb., 77, 823-826, 1978.

Howd, F. H., and H. L. Barnes, Ore solution chemistry IV. Replacement of marble by sulfides at $450^{\circ} \mathrm{C}$, Econ. Geol., 70, 968-981, 1975.

Ildefonse, J.-P., and V. Gabis, Experimental study of silica diffusion during metasomatic reactions in the presence of water at $500^{\circ} \mathrm{C}$ and 1000 bars, Geochim. Cosmochim. Acta, 40, 297-304, 1976.

Lagache, M., New data on the kinetics of the dissolution of alkali feldspars at $200^{\circ} \mathrm{C}$ in $\mathrm{CO}_{2}$ charged water, Geochim. Cosmochim. Acta, 40, 157-162, 1976.

Liou, J。G., and F. W. Dickson, The interaction of $\mathrm{NaCl}$ solution and seawater with andesite, $200^{\circ}-400^{\circ} \mathrm{C}, 500-1000$ bars, EOS, 59, 1221, 1978.

Malinin, S. D., Solubility of fluorspar $\mathrm{CaF}_{2}$ in $\mathrm{NaCl}$ and $\mathrm{HCl}$ solutions under hydrothermal conditions, Geochem. International, 13, 134-138, 1976.

Malinin, S. D., and N. A. Kurovskaya, Solubility of $\mathrm{CO}_{2}$ in chloride solutions at elevated temperatures and $\mathrm{CO}_{2}$ pressures, Geochem. Internat1onal 12, 199-201, 1975.

Mott I, M. J., and H. D. Holland, Chemical exchange during hydrothermal alteration of basalt by seawater - I. Experimental results for rajor and minor components of seawater, Geochirs. Cosmochim. Acta, 42, 1103-1116, 1978.

Novgorodov, P. G., Solubility of quartz in $\mathrm{H}_{2} \mathrm{O}-$ $\mathrm{CO}_{2}$ mixtures at $700^{\circ} \mathrm{C}$ and pressures of 3 and 5 kbar, Geochem. International, 12, 122-126, 1975.

Novgorodov, P. G., On the solubility of quartz in $\mathrm{H}_{2} \mathrm{O}+\mathrm{CO}_{2}$ and $\mathrm{H}_{2} \mathrm{O}+\mathrm{NaCl}$ at $700^{\circ} \mathrm{C}$ and 1.5 $\mathrm{kb}$ pressure, Geochem. International, 14, 191$193,1977$.

Ostapenko, G. T., L. P. Timoshkova, and Yu. I. Goncharov, Free enthalpy of formation of mullite from the data on its solubllity in water at $530^{\circ} \mathrm{C}$ and 1300 bars, Geochem. International, 12, 126-129, 1975.

Popp, R. K., and J. D. Frantz, Solubility of iron in Fe-0-H-S fluids, Carnegie Inst. Wash. Yearb., 76, 601-603, 1977.

Potter, R. W., II, M. A. Clynne, and D. L. Brown, Freezing point depression of aqueous sodium chloride solutions, Econ. Geol., 73, 284-285, 1978.

Radtke, A. S., F. W. Dickson, and D. R. Janecky, Reaction of carbonate rock with $1 \% \mathrm{NaCl}$ solution, $300^{\circ} \mathrm{C}, 1000$ bars, EOS, 59, 1221, 1978.

Sakai, H., and F. W. Dickson, Experimental determination of the rate and disequilibrium fractionation factors of sulfur isotope exchange between sulfate and sulfide in slightly acid solutions at $300^{\circ} \mathrm{C}$ and 1000 bars, Earth Planet. Sci. Lett., 39, 151-161, 1978 .

Seward, T. M., The stability of chloride complexes of silver in hydrothermal solutions up to $350^{\circ} \mathrm{C}$, Geochim. Cosmoch1m. Acta, 40 , 1329-1342, 1976.

Seyfried, W. E., Jr., and W. E. Dibble, Chemical exchange and secondary mineral formation during seawater-peridotite interaction: An experimental study, Geol. Soc. Amer. Abstracts with Programs, 10, 490, 1978.
Vidale, R., Equilibria in the system plagioclasemuscovite-phlogopite-sanidine-quartz-aqueous chloride solution, Carnegie Inst. Wash. Yearb., $74,428-432,1975$.

Wikjord, A. G., T. E. Rummery, and F. E. Doern, Crystallization of pyrite from deoxygenated aqueous sulfide solutions at elevated temperature and pressure, Can. Mineral., 14, 571-573, 1976.

Woor, J. R., Thermodynamics of brine-salt equilibria - II. The system $\mathrm{NaCl}-\mathrm{KCl}-\mathrm{H}_{2} \mathrm{O}$ from 0 to $200^{\circ} \mathrm{C}$, Geochim. Cosmochim. Acta, 40, 1211$1220,1976$.

Wyart, J., The mechanism of the action of water in hydrothermal reactions, Fortschr. Mineral., 52, 169-176, 1975.

\section{Rock Systems}

Cook, L. P。, R. S. Roth, H. S。 Parker, and T. Negas, The system $\mathrm{K}_{2} \mathrm{O}-\mathrm{Al}_{2} \mathrm{O}_{3}-\mathrm{SiO}_{2}$, Part 1 . Phases on the $\mathrm{KAlSiO}_{4}-\mathrm{KAlO}_{2}$ join, Amer. Mineral., 62, 1180-1190, 1977.

Cooper, A. F., J. Gittins, and 0. F. Tuttle, The system $\mathrm{Na}_{2} \mathrm{CO}_{3}-\mathrm{K}_{2} \mathrm{CO}_{3}-\mathrm{CaCO}_{3}$ at 1 kilobar and its significance in carbonatite petrogenesis, Amer。 Jo Sci., 275, 534-560, 1975.

Day, $H$. W., A working model of some equilibria in the system alumina-silica-water, Amer. J. Sci., 276, 1254-1284, 1976.

Finnerty, T. A., Exchange of $\mathrm{Mn}, \mathrm{Ca}, \mathrm{Mg}$, and $\mathrm{Al}$ between synthetic garnet, orthopyroxene, clinopyroxene, and olivine, Camegie Inst. Wash. Yearb., 76, 572-579, 1977.

Giblin, A. M., Experiments to demonstrate mobility of metals in waters near base-metal sulphides, Chem. Geo1., 23, 215-224, 1978.

Hemley, J. J., J.W. Montoya, C. L。 Christ, and P. B. Hostetler, Mineral equilibria in the $\mathrm{MgO}-\mathrm{SiO}_{2}-\mathrm{H}_{2} \mathrm{O}$ system: I. talc-chrysotileforsterite-brucite stability relations, Amer. J. Sc1., 277, 322-351, 1977a.

Hemley, J. J., J. W. Montoya, D. R. Shaw, and R. W. Luce, Mineral equilibria in the MgO$\mathrm{SiO}_{2}-\mathrm{H}_{2} \mathrm{O}$ system: II. Talc-antigoriteforsterite-anthophyllite-enstatite stability relations and some geologic implications in the system, Amer. J. Sc1., 277, 353-383, $1977 \mathrm{~b}$.

Hoda, S. No, and L. $\mathrm{L}_{\circ}$ Y. Chang, Phase relations in the systems $\mathrm{PbS}-\mathrm{Ag}_{2} \mathrm{~S}-\mathrm{Sb}_{2} \mathrm{~S}_{3}$ and $\mathrm{PbS}-\mathrm{Ag}_{2} \mathrm{~S}-$ $\mathrm{Bi}_{2} \mathrm{~S}_{3}$, Amer. Minera1., 60,621-633, 1975.

Hoffer, E., The reaction sillimanite + biotite + quartz $=$ cordlerite $+\mathrm{K}$-feldspar $+\mathrm{H}_{2} \mathrm{O}$ and partial melting in the system $\mathrm{K}_{2} \mathrm{O}-\mathrm{FeO}-\mathrm{MgO}-$ $\mathrm{Al}_{2} \mathrm{O}_{3}-\mathrm{SiO}_{2}-\mathrm{H}_{2} \mathrm{O}$, Contr. Mineral. Petrol., 55, 127-130, 1976 .

Holdaway, M. Jo, Mutual compatibility relations of the $\mathrm{Fe}^{+2}-\mathrm{Mg}-\mathrm{Al}$ silicates at $800^{\circ} \mathrm{C}$ and $3 \mathrm{~kb}$, Amer. J. Sci., 276, 285-308, 1976.

Ivanov, I. P., and I. P. Gurevich, Experimental study of $\mathrm{T}-\mathrm{X}_{\mathrm{CO}}$ boundaries of metamorphic zeolite facies, Contr. Mineral. Petrol., 53, $55-60,1975$.

Ohmoto, $H_{\circ}$, and D. Kerrick, Devolatilization equilibria in graphitic systems, Amer. J. Sci., 277, 1013-1044, 1977.

Slaughter, J。, D. M. Kerrick, and V。 J. Wall, Experimental and thermodynamic study of equilibria in the system $\mathrm{CaO}-\mathrm{MgO}-\mathrm{SiO}_{2}-$ 
$\mathrm{H}_{2} \mathrm{O}-\mathrm{CO}_{2}$, Amer。J. Sci。, 275, 143-162, 1975.

Triboulet, C., Experimental study of clay mineral, greenschist, and low-pressure amphibole facies in the system $\mathrm{Na}_{2} \mathrm{O}-\mathrm{Al}_{2} \mathrm{O}_{3}-\mathrm{MgO}-\mathrm{SiO}_{2}-\mathrm{H}_{2} \mathrm{O}$, Mineral. Mag. , 40, 875-886, 1976.

Warner, R. D., New experimental data for the system $\mathrm{CaO}-\mathrm{MgO}-\mathrm{SiO}_{2}-\mathrm{H}_{2} \mathrm{O}$ and a synthesis of inferred phase relations, Geochim. Cosmochim. Acta, 39, 1413-1422, 1975.

Zharikov, V. A., K. I. Shmulovich, and V. K. Bulatov, Experimental studies in the system $\mathrm{CaO}-\mathrm{MgO}-\mathrm{Al}_{2} \mathrm{O}_{3}-\mathrm{SiO}_{2}-\mathrm{CO}_{2}-\mathrm{H}_{2} \mathrm{O}$ and conditions of high-temperature metamorphism, Tectonophysics, 43, 145-162, 1977.

VOL. 17 , No. 4

REVIEWS OF GEOPHYSICS AND SPACE PHYSICS

JUNE 1979

\section{VOLCANOLOGY}

Tom Simkin

Smithsonian Institution, Washington, D.C. 20560

Volcanology in the 1970s has expanded greatly in both size and scope. Comparison of the references 1 isted here with those of the U.S. National Report to IUGG for 1963-6 (by R. W. Decker) and 1967-70 (by T. L. Wright)* illustrates many of these changes. The number of references has doubled, reflecting increased interest in active volcanoes as well as the overall increase in scientific literature. Kilauea has been at least twice as active as any other oceanic volcano during the last decade, and Its references (48) continue to dominate work on individual U.S. volcanoes. Alaskan volcanoes, 33 of which have erupted in the last 100 years, continue to be the most neglected of U.S. volcanoes (total of 24 references). On the other hand, those of the western conterminous U.S., only one of which is known to have erupted in the last 100 years, have recelved far more attention in the 1970 s (21\% of the references here, compared with $14 \%$ and $7 \%$ in the '67-70 and '63-66 reports, respectively). Much of this increased attention stems from the search for geothermal power, and heightened awareness of volcanic hazards.

The most striking volcanological advances of the 1970s, however, have been in the investigation of deep sea volcanism. The recognition that most of the world's volcanic activity is submarine, matched with technological advances in marine exploration, have led to exciting new discoveries on the sea floor. Continental segments of the world's rift systems have also benefited from increased volcanological attention. Additional recent expansion in 1970s volcanology has come with interdisciplinary approaches: the application of physics and chemistry to eruptive processes, the meteorological effects of explosive eruptions, the geophysical delineation of subsurface magma bodies, and the increasing interaction with archeological problems.

Previous U.S. National Reports to the IUGG have reviewed volcanological findings at Hawailan,

\footnotetext{
*Volcanology was not reviewed in the 1971-4 report. Several important references appearing during this period, if not listed in the author's subsequent work, have been included in this bibliography and the 1970's are reviewed as a whole in the text.
}

Th1s paper is not subject to U.S. copyright. Published in 1979 by the American Geophysical Union.
Alaskan, and western U.S. volcanoes, and provided tahplar summaries of the volcanic activity at each region during the report periods through 1970. The years since 1970 , however, have all been reviewed in each January issue of Geotimes, and additional chronologic detail can be found in several references cited below (under "Surveiliance"). U.S. volcanoes have produced an average of 3.4 eruptions per year $(\sigma=1.8)$ during the last two decades, with no remarkable variation in the 1970s. Consequently, this review will carry no chronologic summary, although outstanding volcanic events will be woven into the review. The review will be organized around the main subject areas of volcanologic research, but the accompanying bibliography contains a letter code to facilitate rapid identification of references in major geographic areas. In a general way, the review will move from effusive rift volcanism, through intraplate activity, to the explosive volcanism of island arcs and continental margins, before treating meteorological and socioeconomic aspects of volcanoes.

\author{
Subaerial lava: \\ flood basalts, flows, \\ forms, \& lava lakes
}

Flood basalts must be one of the most dramatic forms of volcanism, but they have never been witnessed by man. The most recent known are those of the Columbla Plateau, northwestern U.S., most of which erupted 15 milifion years ago. Recent work by Swanson, Wright, and others has shown that single flows measuring $700 \mathrm{~km}^{3}$ have spread over $10^{3} \mathrm{~km}^{2}$ in a few days. This eruption rate ( $1 \mathrm{~km} /$ day per $\mathrm{km}$ of active fissure) is $2-3$ orders of magnitude greater than sustained rates observed on Hawail. The largest historic lava eruption was from the $10 \mathrm{~km}$ Lakagigar fissure in Iceland, when $10 \mathrm{~km}^{3}$ covered $370 \mathrm{~km}^{2}$ during 50 days in 1783 (Thorarinsson, 1969). Iceland also now holds the record for the smallest, historic lava eruption known, after $1 \mathrm{~m}^{3}$ of magma was extruded from a Krafla drill hole in 1977.

Hawail's largest and longest historic flank eruption ended in 1974, and provided many opportunities for the study of moving lava. The full course of the 5 year eruption is reviewed by Peterson et al. (1976) and its vigorous first 17 months, including dramatic lava falls into pit craters and the construction of the small shield volcano Mauna $\mathrm{Ulu}$, is described in detail by Swanson et al. (1979). The formation of lava 